\title{
Feather mercury levels in seabirds at South Georgia: influence of trophic position, sex and age
}

\author{
Peter H. Becker ${ }^{1, *}$, Jacob González-Solís ${ }^{2}$, Brigitte Behrends ${ }^{1}$, John Croxall ${ }^{3}$ \\ ${ }^{1}$ Institut für Vogelforschung 'Vogelwarte Helgoland', An der Vogelwarte 21, 26386 Wilhelmshaven, Germany \\ ${ }^{2}$ Departamento Biología Animal (Vertebrats), Universitat de Barcelona, Avenida Diagonal 645, 08028 Barcelona, Spain \\ ${ }^{3}$ British Antarctic Survey, Natural Environment Research Council, High Cross, Madingley Road, Cambridge CB3 0ET, \\ United Kingdom
}

\begin{abstract}
We studied the mercury contamination of 13 species of seabirds breeding on Bird Island, South Georgia, in 1998. Total mercury concentrations in body feather samples of birds caught at their breeding colonies were determined. Among the species, grey-headed albatross $\left(8933 \mathrm{ng} \mathrm{g}^{-1}\right)$ and southern giant petrel (7774 $\mathrm{ng} \mathrm{g}^{-1}$ ) showed the highest, and gentoo penguin $\left(948 \mathrm{ng} \mathrm{g}^{-1}\right)$ the lowest body feather mercury concentrations. Mercury levels were negatively correlated with the proportion of crustaceans (mainly krill) in the species' diets, suggesting that the trophic level is the most important factor in explaining the variation of mercury concentrations in Antarctic seabirds. In 4 species studied for age effects among adult birds (grey-headed and black-browed albatross, northern and southern giant petrel), no age-dependent variation in mercury levels was found. Sex differences were also assessed: female gentoo penguins had lower mercury levels than males, which may be related to the elimination of part of the mercury body burden by females into eggs. In contrast, northern giant petrel males had lower levels than females, which may be related to a higher consumption by males of carrion from Antarctic fur seals. In grey-headed albatrosses, mercury levels were $113 \%$ higher than in 1989, when this species was investigated at the same site, indicating a possible increase in mercury pollution of the Southern Ocean during the last decade.
\end{abstract}

KEY WORDS: Interspecific variability · Intraspecific variability $\cdot$ Trophic position $\cdot$ Krill diet $\cdot$ Foraging Temporal trend $\cdot$ Total mercury $\cdot$ Body feathers

\section{INTRODUCTION}

Many seabird species occupy high positions in marine food chains and biomagnify persistent environmental chemicals. Consequently, they are useful as accumulative indicators to monitor the contamination of marine environments with heavy metals and other pollutants (e.g. Elliott et al. 1992a, Furness 1993, Bignert et al. 1995, Monteiro \& Furness 1995, Becker et al. 1998, 2001, Burger \& Gochfeld 2002). Seabirds offer various levels of ecological, spatial and temporal integration, and have been chosen as cost-effective and successful monitors, particularly of environmental con-

*Email: peter.becker@ifv.terramare.de tamination of mercury (reviewed e.g. by Furness 1993, Furness et al. 1995, Monteiro \& Furness 1995, Monteiro et al. 1998). They integrate mercury contamination over marine food webs and reflect its hazards to marine ecosystems and humans better than abiotic samples (Burger 1993, ICES 1999).

Seabirds experimentally fed with a diet enriched with mercury eliminate the metal ingested in a dosedependent fashion into eggs and plumage, and are able to excrete from 33 to $60 \%$ of the body mercury burden into the growing feathers during moult or growth in young (Lewis \& Furness 1991, Monteiro \& Furness 2001a,b). Bonaparte's gulls Larus philadelphia remove 59 to $68 \%$ of their body mercury burden into the plumage by moult (Braune \& Gaskin 1987). Almost $100 \%$ of the mercury in feathers was found to be 
methylmercury (Thompson \& Furness 1989), and studies on seabird corpses showed that the plumage of an adult bird contains between 73 and $93 \%$ of its total body burden of mercury (Honda et al. 1986, Braune 1987). Simultaneous analyses of both blood and feathers have shown that during growth mercury levels in feathers are strongly and positively related to the levels in blood (Kahle \& Becker 1999, Monteiro \& Furness 2001a). Even if the kinetics of mercury in birds' bodies is only partly understood (see Monteiro \& Furness 2001a,b), feathers are clearly the main elimination pathway for mercury in birds, decontaminating the body from the burden accumulated during the period before moult.

Consequently, levels of mercury in feathers can be used as an effective index of a bird's contamination. Furthermore, feathers provide easily obtainable and relatively non-invasive matrices for monitoring. Time series of feather samples from seabirds both in the NE Atlantic (Thompson et al. 1992a, 1993a, Monteiro \& Furness 1997) and from some seabird species in the Southern Ocean (Thompson et al. 1993b) have revealed significant increases in mercury concentrations in seabirds during the 20th century, owing to increased mercury emissions transported and deposited by the atmosphere around the world.

In this paper, we use body feathers to present information on the recent mercury levels in a community of 13 seabird species breeding on Bird Island, South Georgia. The ecological long-term studies of marine birds by the British Antarctic Survey allowed investigation of some important aspects of the level and variability of mercury in these seabirds. As numerous birds have been individually marked with rings during the last 50 yr, many can be aged and also sexed.

We address the following topics: (1) The number of species (13) involved in our study may clarify the relationship between mercury levels and the trophic position of marine birds (cf. Monteiro et al. 1995, 1998, 1999, Mattig et al. 2000). Recently several studies have provided new and detailed information on the foraging ecology of Bird Island seabirds (see review by Croxall \& Prince 1987). This knowledge may help to explain interspecific differences in mercury levels found in the seabird community. (2) In 1998, we repeated feather sampling from adult birds of 2 species (black-browed albatross Diomedea melanophris and grey-headed albatross Diomedea chrysostoma), studied in 1989 by Thompson et al. 1993, in order to assess temporal trends in mercury pollution in the South Atlantic Ocean. (3) We investigated possible age effects on mercury levels in adult seabirds, which to date have not been detected by other studies (Furness et al. 1990, Thompson et al. 1991, 1993a). (4) Sex is known to affect mercury dynamics and levels in some tissues in seabirds, but to have no or only small effects on body feather mercury levels (Furness et al. 1990, Thompson et al. 1991, Lewis et al. 1993, Monteiro \& Furness 2001b). We studied possible sex effects in 2 species of penguins, macaroni Eudyptes chrysolophus and gentoo penguin Pygoscelis papua, and in the 2 species of giant petrels, Macronectes halli and M. giganteus, characterised by sexual dimorphism (e.g. GonzálezSolís et al. 2000a), which is linked with their foraging ecology and may be reflected in differences in mercury levels of the sexes (González-Solís et al. 2000b).

\section{MATERIALS AND METHODS}

Sampling. Feather sampling was carried out on Bird Island, South Georgia (54 03' S, 38 36' W), between 29 September and 9 December 1998. We sampled adult birds during the pre-breeding or the incubation period except for wandering albatrosses Diomedea exulans, for which only mature chicks were available. The 13 species and sample sizes used for mercury analyses are given in Fig. 1 and Table 1. Penguins (Sphenisciformes): gentoo penguin, macaroni penguin; albatrosses, shearwaters and petrels (Procellariiformes): wandering albatross (chick), black-browed albatross, greyheaded albatross, northern giant petrel, southern giant petrel, white-chinned petrel Procellaria aequinoctialis, blue petrel Halobaena caerulea, common diving petrel, South Georgian diving petrel Pelecanoides georgicus; cormorants (Phalacrocoracidae): blue-eyed shag Phalacrocorax atriceps georgicus; skuas (Stercorariidae): brown skua Catharacta lonnbergi.

Sexing: Gentoo penguins, northern and southern giant petrels were sexed by bill measurements (Renner et al. 1998, González-Solís et al. 2000a). Macaroni penguins were sexed according to the arrival time at the colony during the pre-breeding period, males arriving 1 wk before females. For albatrosses, birds had already been sexed as part of long-term population studies.

Age: With the exception of chicks in wandering albatrosses, only adult birds were included in feather sampling. Because many individuals had been ringed as chicks or as adults, we could age some individuals of black-browed albatross (age range 12 to $50 \mathrm{yr}$ ), greyheaded albatross (11 to $38 \mathrm{yr}$ ), northern giant petrel (10 to $27 \mathrm{yr}$ ) and southern giant petrel (10 to $27 \mathrm{yr}$ ). Six black-browed albatrosses and 6 southern giant petrels ringed as adults were included on the basis of their minimum possible age.

A total of 4 to 7 breast feathers per individual were taken. Feathers were transported and stored in envelopes and at room temperature. Since breast feathers in large seabirds are generally considered to be 
moulted all year round, possible effects of moulting on mercury levels of individual feathers are minimised by using several body feathers (Furness et al. 1986), and average values of mercury content of 2 to 4 feathers can be regarded as providing a temporal integration of the mercury levels over the year.

Mercury analysis. For mercury analyses, we grouped the birds into age and sex classes when possible. Each of 2 to 4 feathers sampled per bird was analysed separately for mercury concentration in the chemical laboratory of the research centre TERRAMARE, Germany. The feathers were washed alternately with bidistilled water and acetone (p.a. grade) in an ultrasonic bath. Small feathers can be digested as they are, bigger feathers have to be cut into smaller pieces. For digestions, after Kruse (1979), ca. 50 mg feather material was blended in a graduated test tube with $3 \mathrm{ml}$ digestion acid, a mixture of chloric, nitric and perchloric acid (60:40:6). All chemicals were of analytical grade and obtained from Merck. The tube was closed with a capillary stopper and heated in a dry block to $145^{\circ} \mathrm{C}$ for $2 \mathrm{~h}$. After cooling the sample, the graduated test tubes were filled up with bidistilled water up to the desired volume. Although the samples should be digested completely, filtration of the solutions with GF/C-filter (Whatman) is recommended. A flow injection mercury system (FIMS 400, Perkin Elmer) with an integrated flow injection module of the flow injection analysis system (FIAS 400, Perkin Elmer) was used for the measurement. For mercury determination, a carrier and a reductant solution are needed. The carrier solution was hydrochloric acid $(1 \%)$ and the reductant solution was stannous(II)-chloride-dihydrate (12.5 $\left.\mathrm{g} \mathrm{l}^{-1}\right)$ in hydrochloric acid (1\%). For calibration of the FIMS, 6 standard solutions with mercury concentrations of $0.5,1,2,5,10$ and $20 \mathrm{ppb}$ were prepared. The limit of determination for mercury was $0.1 \mathrm{ng} \mathrm{g}^{-1}$.

Statistics. Given the generally low variance between body feathers in seabirds (Thompson et al. 1993a), an arithmetic mean concentration of the 2 to 4 feathers measured was calculated for each bird. As mercury concentrations were not different from a normal distribution for any species, we used parametric statistics, ANOVA and Dunnett-T3 multiple comparisons for inhomogenous variances as well as $t$-tests. Arithmetic means and standard deviations are presented if not otherwise stated. We used 2 approaches to analyse the data for age effects. First, we correlated age with the mercury concentration (Pearson) and second, we classified the birds into 2 age groups: 10 to 19 and $\geq 20 \mathrm{yr}$. In addition, correlation coefficients of mercury concentration with diet composition (after Croxall \& Prince 1987; Spearman, Table 1) were calculated. All tests were 2-tailed and have a level of significance of $\mathrm{p}<0.05$.

\section{RESULTS}

\section{Interspecific differences}

Our data revealed distinct interspecific differences in mercury feather levels, which were significant between many species (Fig. 1, Table 1). Three groups of species can be classified with respect to their feather mercury burden, verified by the Duncan multiple comparisons test (5 homogeneous subgroups). The first group, of low mercury concentrations, was represented by the gentoo penguin. Because of small sample size, the 2 other species showing low feather levels, common diving petrel and South Georgian diving petrel, have not been included in the statistical tests. Most species were characterised by medium levels in the range between 3309 and $5390 \mathrm{ng} \mathrm{g}^{-1}$ (Subgroup 2, including the brown skua with $3965 \pm 1641 \mathrm{ng} \mathrm{g}^{-1}$ ). Both the grey-headed albatross (Subgroup 5) and the southern giant petrel (Subgroups 4 and 5) showed significantly higher mercury levels than most other species of the community. The blue-eyed shag (Subgroups 3 and 4) was intermediate between the species of medium and high mercury levels.

Grey-headed albatrosses had higher mercury levels than black-browed albatrosses (Fig. 1). Southern giant petrels had higher feather mercury levels than northern giant petrels but the difference was not significant in the multiple comparison (Fig. 1); comparing the 2 giant petrels separately, however, the difference was significant $\left(T_{64}=-3.053, \mathrm{p}=0.003\right)$. The higher mer-

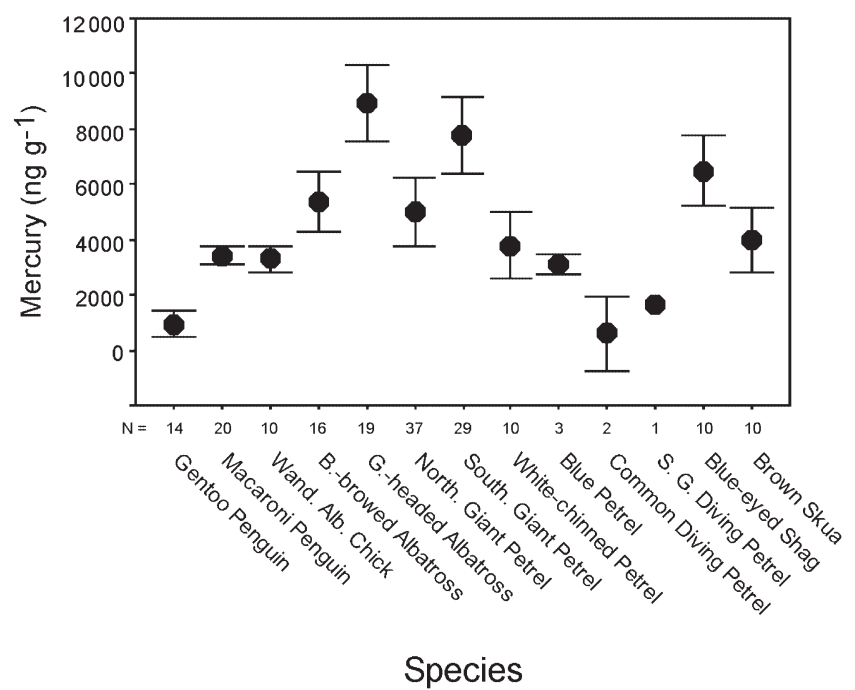

Fig. 1. Mercury levels (ng $\mathrm{g}^{-1}$ fresh weight) in feathers of 13 seabird species at Bird Island, South Georgia, in 1998. Means $\pm 95 \%$ confidence intervals. With the exception of wandering albatross chicks, the feathers were taken from adult birds during the breeding period 
cury levels of southern giant petrels than northern giant petrels was mainly due to the low values of mercury concentration in northern giant petrel males (see also below and Table 2: giant petrel males $T_{27}=-3.053$, $\mathrm{p}=0.008$; giant petrel females $T_{35}=-2.025, \mathrm{p}=0.051$ )

In wandering albatross chicks mercury concentrations $\left(3309 \pm 678 \mathrm{ng} \mathrm{g}^{-1}\right)$ were lower than in adults of grey-headed and black-browed albatross and southern giant petrel. Macaroni penguins were more contaminated than gentoo penguins (Fig. 1).

\section{Mercury levels and trophic position}

To study influences of the trophic position on mercury level of the species investigated, we linked the mercury findings with information on diets of the South Georgia seabirds sampled. In general, species feeding on fish also consume higher proportions of squid and conversely, low proportions of crustaceans (Table 1). A clear relationship between mercury levels and trophic position was evident: species with high dietary proportions of crustaceans, mainly krill, had lower mercury feather concentrations than species whose diet is characterised by higher proportions of fish (and/or squid; Table 1, Fig. 2), and which accordingly feed at higher trophic levels.

\section{Age effects}

In the 4 species with birds of known age, we investigated possible age effects on the level of mercury. No significant correlations with age were found (grey-headed albatross, $r=$ 0.107, $\mathrm{p}=0.664, \mathrm{n}=19$; black-browed albatross, $\mathrm{r}=-0.027, \mathrm{p}=0.920, \mathrm{n}=16$; northern giant petrel, $\mathrm{r}=-0.011, \mathrm{p}=$ $0.946, \mathrm{n}=37$; southern giant petrel, $\mathrm{r}=$ 0.054, $\mathrm{p}=0.781, \mathrm{n}=29$ ). Furthermore, classifying the birds according to age and sex (Table 2) revealed no significant variation of mercury levels with age, although southern giant petrel males tended to have higher feather levels when becoming older. A weak tendency towards increasing levels with age was found in all 4 species, except male northern giant petrels and female southern giant petrels.

\section{Sex effects}

Giant petrel females contained higher mercury levels than males (Table 2: northern giant petrel, $F=$ $6.374, \mathrm{p}=0.017$; southern giant petrel, $F=3.803, \mathrm{p}=$ 0.067 ). In the penguins studied, males had higher contamination than females, significantly so in gentoo penguins ( $p=0.016$, Table 3$)$.

\section{DISCUSSION}

\section{Interspecific variability}

As mercury levels in the plumage are strongly and positively related to a bird's body burden (see references in 'Introduction'), and as body feathers can be

Table 1. Relationships between diet and feather mercury levels (means $\pm \mathrm{SD}$, n in brackets; cf. Fig. 1). Diet data from Croxall \& Prince (1987). Crustaceans include mainly krill but also copepods (in common diving petrels $68 \%$ of diet), amphipods and other crustaceans

\begin{tabular}{|lcrrrr|}
\hline Species & Mercury & \multicolumn{3}{c|}{ Diet (\% by weight) } \\
& $\begin{array}{c}\text { concentration } \\
\left(\mathrm{ng} \mathrm{g}^{-1}\right)\end{array}$ & $\begin{array}{c}\text { Crusta- Squid } \\
\text { ceans }\end{array}$ & Fish & Other \\
\hline Gentoo penguin & $948 \pm 848(14)$ & 68 & 0 & 32 & 0 \\
Macaroni penguin & $3412 \pm 732(20)$ & 98 & 0 & 2 & 0 \\
Black-browed albatross & $5391 \pm 2049(16)$ & 40 & 21 & 39 & 0 \\
Grey-headed albatross & $8933 \pm 2851(19)$ & 16 & 49 & 35 & 0 \\
Northern giant petrel & $4988 \pm 3762(37)$ & 15 & 6 & 2 & 77 \\
Southern giant petrel & $7774 \pm 3571(29)$ & 12 & 2 & 1 & 85 \\
White-chinned petrel & $3790 \pm 1717(10)$ & 28 & 47 & 24 & 0 \\
Blue petrel & $3098 \pm 143(3)$ & 91 & 1 & 8 & 0 \\
Common diving petrel & $594 \pm 150(2)$ & 100 & 0 & 0 & 0 \\
South Georgia diving petrel & $1631(1)$ & 100 & 0 & 0 & 0 \\
Blue-eyed shag & $6481 \pm 1781(10)$ & 10 & 20 & 70 & 0 \\
r mercury with diet $(\mathrm{n}=11)$ & & -0.829 & 0.796 & 0.493 & \\
p & & 0.002 & 0.003 & 0.123 & \\
\hline
\end{tabular}

Table 2. Age- and sex-specific differences in feather mercury levels of seabird species from South Georgia, 1998. Means \pm SD (n) in $\mathrm{ng} \mathrm{g}^{-1}$ are presented. Differences between age groups were not significant, but differences between the sexes in northern giant petrels were significant (2-way ANOVA; sex $F=6.374, \mathrm{p}=0.017)$

\begin{tabular}{|c|c|c|c|}
\hline \multirow{2}{*}{ Species } & \multirow{2}{*}{ Sex } & \multicolumn{2}{|c|}{ Age (yr) } \\
\hline & & 10 to 19 & $\geq 20$ \\
\hline Grey-headed albatross ${ }^{a}$ & - & $8653 \pm 2224(10)$ & $9245 \pm 3537(9)$ \\
\hline Black-browed albatross & Male & $4948 \pm 1242(10)$ & $6128 \pm 2962$ \\
\hline \multirow{2}{*}{ Northern giant petrel } & Male & $3749 \pm 2342$ & $2822 \pm 2769$ \\
\hline & Female & $5485 \pm 3337(11)$ & $7071 \pm 4894(10)$ \\
\hline \multirow[t]{2}{*}{ Southern giant petrel } & Male & $4951 \pm 2264$ & $7422 \pm 3727$ \\
\hline & Female & $9005 \pm 2717(10)$ & $8544 \pm 4762(6)$ \\
\hline
\end{tabular}




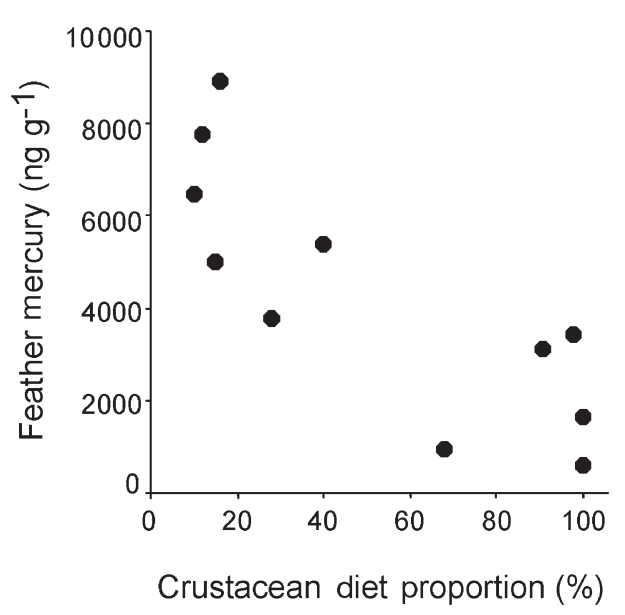

Fig. 2. Negative relationship between mercury levels (ng g ${ }^{-1}$ fresh weight) in adult feathers and the proportion of crustaceans (mainly krill) in the diet of 11 seabird species from South Georgia, in 1998. Diet information after Croxall \& Prince (1987). See Table 1 for further information on the species, diets and statistics

assumed to be moulted continuously during the year, body feathers may well be used to indicate the overall body mercury load of an individual bird over the year. Interspecific variability of mercury burdens in seabirds is mainly attributed to diet, although other factors such as moult patterns, foraging or migratory areas have also been recognised (Walsh 1990, Lock et al. 1992, Becker et al. 1993, Stewart et al. 1999). With respect to the community of coastal birds, there is a general tendency for mercury concentrations to be highest in those species feeding on fish (Braune 1987, Mattig et al. 2000) which contain higher mercury levels than marine invertebrates (e.g. Mattig et al. 1997).

Although previous studies found no clear patterns and associations of mercury levels with diets (Muirhead \& Furness 1988, Elliott et al. 1992b), recent studies on seabirds could relate mercury concentrations to the mercury burden of their prey (Monteiro et al. 1995, 1996, 1998, Stewart et al. 1999, Arcos et al. 2002). Mercury is the heavy metal showing the clearest biomagnification in food chains (Honda et al. 1987, Atwell et al 1998). Thus, those seabird species feeding

Table 3. Sex differences in mercury feather levels of gentoo and macaroni penguins from South Georgia in 1998. Means $\pm \mathrm{SD}(\mathrm{n})$ in $\mathrm{ng} \mathrm{g}^{-1}$ and $\mathrm{p}$-values ( $t$-test) are presented

\begin{tabular}{|lccc|}
\hline Species & Males & Females & $p$ \\
\hline Gentoo penguin & $1191 \pm 892(10)$ & $340 \pm 192(4)$ & 0.016 \\
Macaroni penguin & $3705 \pm 655(10)$ & $3135 \pm 723(10)$ & 0.081 \\
\hline
\end{tabular}

on fish or squid are expected to have higher levels of mercury than species feeding on lower trophic levels. This effect, however, is predicted not only because of the biomagnification of mercury in fish and squid compared to prey of lower trophic levels but also because many species of fish and squid are mesopelagic $(<200 \mathrm{~m})$, and become available to seabirds by $\mathrm{mi}-$ grating into epipelagic zones at night. In such subthermocline deep-water species, mercury levels are higher, presumably due to methylation of mercury in deep low oxygen water, thereby permitting greater assimilation of mercury into biota (Monteiro et al. 1996, 1998, Thompson et al. 1998).

In Antarctic food webs, bioaccumulation and biomagnification of mercury have also been recognised (Honda et al. 1987, De Moreno et al. 1997, Bargagli et al. 1998). In the South Georgia seabird community, a clear relationship between the mercury level and the trophic position was evident: species with high proportions of crustaceans, mainly krill, in their diets had lower mercury feather concentrations than species feeding at higher trophic levels, and whose diet is characterised by higher proportions of squid and/or fish (Table 1, Fig. 2). Crustaceans, and particularly krill, have previously been identified as a key factor explaining mercury concentrations in marine biota (food chain: Honda 1987; seals: Szefer et al. 1993; cetaceans: Bowles 1999), including seabird communities (Lock et al. 1992, Steward et al. 1999). This result is corroborated in this study by a clear and statistically significant relationship between amounts of krill in the diet and levels of mercury. The dietary information compiled by Croxall \& Prince (1987) and used here was confirmed by later longer-term studies on some of the species (Croxall et al. 1997). Our results suggest that the length of the food chain, in particular in relation to krill consumption, is the key factor for explaining patterns of mercury levels at seabird community level, although bioaccumulation may be enhanced by the consumption of some vertically migratory mesopelagic prey (Monteiro et al. 1998).

Differences in mercury concentrations could also be related to physiological differences among seabird taxa, as has been shown for levels in liver (Walsh 1990). Especially high mercury concentrations have been found in internal tissues and feathers of large albatrosses (Muirhead \& Furness 1988, Lock et al. 1992, Thompson et al. 1993b, Hindell et al. 1999). This is confirmed by our study. Slow moult patterns were suggested as the likely major reason for this, but small procellariiforms with annual moult cycles also exhibit such enhanced mercury levels, e.g. the White-chinned and Blue Petrels in our study (Fig. 1). Monteiro et al. (1995) suggested peculiarities of the metal dynamics as possible reasons for the high mercury burdens 
within this taxonomic group. However, Stewart et al. (1999) showed that phylogeny was a minor factor in explaining mercury levels in New Zealand procellariiforms. In our study, differences between mercury levels between closely related species were often more pronounced than between seabird families (Fig. 1), suggesting that ecological factors are more relevant for mercury levels than phylogenetic relationships.

Foraging area may also be important in determining mercury levels. This seems to be the case with gentoo and macaroni penguins, though krill makes up a large proportion of the food of both species. During summer gentoo penguins feed inshore and macaroni penguins offshore (Croxall \& Prince 1987, Reid et al 1996), the first feeding more extensively on fish than the second (gentoo penguin, 68\% crustaceans and 32\% fish; macaroni penguin, 98\% crustaceans and 2\% fish). Blue-eyed shag was another inshore feeding species, but with a great proportion of fish in its diet (Table 1, Croxall \& Prince 1987) characterised by high feather mercury levels (6481 ng g ${ }^{-1}$ ). De Moreno et al. (1997) also found relatively high mercury levels in tissues of this species and discussed the possibility that the mercury intake originates from their migration to more contaminated South American coasts. Indeed, in body feathers of 3 individuals of this species found dead near Punta Arenas, southern Chile in 1995, high mercury levels of $4166 \mathrm{ng} \mathrm{g}^{-1}$ were measured, ( $\mathrm{n}=3$; P. H. Becker unpubl. data), indicating generally high mercury burdens in this species. In contrast to the South American situation, however, the blue-eyed shag population at South Georgia is resident yearround.

The highest feather mercury concentrations were found in grey-headed albatrosses, even higher than those of black-browed albatrosses. This difference agrees with liver mercury concentrations reported in both species from New Zealand (28.2 and $20.7 \mathrm{\mu g} \mathrm{g}^{-1}$ dry weight for grey-headed and black-browed albatross, respectively; Lock et al. 1992). The diet of greyheaded albatrosses is characterised by smaller proportions of krill and higher proportions of squid than that of black-browed albatrosses (Croxall \& Prince 1987). In this case, differences in the consumption of mesopelagic and epipelagic fish and squid species (Monteiro et al. 1998) may be linked with the observed interspecific difference in mercury levels.

Low mercury levels in the plumage were found in common diving petrel and South Georgian diving petrel. The small sample sizes, however, preclude a general statement on mercury levels of these petrel species. Common diving petrel liver mercury concentrations were also reported to be very low in comparison with other species (Muirhead \& Furness 1988, Lock et al. 1992). Both species of diving petrels predomi- nantly feed inshore on marine organisms of the lower trophic levels: krill (common diving petrel 15\% by weight, South Georgian diving petrel 76\%; Croxall \& Prince 1987), copepods (68 and 20\%) and amphipods (17 and $4 \%$ )

To summarise, the mercury feather concentrations in the seabird community studied showed strong relationships to the trophic level of the species, with increasing levels of mercury in relation to decreasing proportions of krill in the diet. Some findings, however, cannot be explained by diets alone, and moult strategies and foraging areas may also be involved.

\section{Intraspecific variability}

Intraspecific variability in mercury burdens is poorly understood, but several factors such as age, sex, season, dietary and foraging area specialisation, and their combinations have been suggested (Walsh 1990, Monteiro \& Furness 2001b). We did not find significant effects of adult age on mercury feather levels in any of the 4 species studied. This accords with earlier results from black-browed, grey-headed and wandering albatrosses (Thompson et al. 1993b), which moult infrequently and irregularly (Furness 1988, Weimerskirch 1991), and from other species such as red-billed gulls Larus novaehollandiae scopulinus (Furness et al. 1990), great skuas Catharacta skua (Thompson et al. 1991) and common terns Sterna hirundo (Burger et al. 1994), which moult more regularly. The independence between feather mercury levels and bird age may be explained by the (usually annual) moult being an effective way of decontaminating the body mercury burden (see 'Introduction'). In addition, especially procellariiforms may demethylate ingested mercury into inorganic mercury and store this in internal tissues (Thompson \& Furness 1989, Lock et al. 1992; but see Monteiro 1996). An indication that total mercury loads in internal tissues may be age-dependent was recently presented by Hindell et al. (1999), who showed that adult wandering albatrosses had higher liver mercury levels than juvenile birds.

There is evidence that mercury dynamics varies between the genders in procellariiform species owing to reproductive processes. Monteiro \& Furness (2001b) argued that sex-related differences in physiology may be a cause of the inter-sex differences observed in the blood dose-response in Cory's shearwater Calonectris diomedea. However, many studies found no sexual differences in mercury burdens in internal tissues; in particular, body feather levels have been reported to be fairly independent of sex (red-billed gulls, Furness et al. 1990; great skua, Thompson et al. 1991; herring gulls Larus argentatus, Lewis et al. 1993). Lower con- 
centrations of mercury in females are occasionally found (tissues of common murres Uria aalge, Stewart et al. 1994; female Primary 1 of herring gulls, Lewis et al. 1993; Primaries 1 to 5 of Bonaparte's gull, Braune \& Gaskin 1987) as well as slightly lower concentrations in feathers compared to males, probably indicating an additional depletion of female body mercury burdens by the route of egg production (Becker 1992, Lewis et al. 1993). In our study, the higher levels in male compared with female gentoo penguins, as well as the tendency towards higher mercury feather levels in male macaroni penguins, are consistent with such suggestions.

However, higher values of mercury burdens in females are rarely reported (e.g. in liver of female wandering albatrosses; Hindell et al. 1999). In this study, we found that northern giant petrel females showed significantly higher levels of mercury than males, and we found a similar tendency for southern giant petrels, although differences were just non-significant (Table 2). These differences can be attributed to dietary segregation between sexes in both species. Male and female giant petrels display sex-specific foraging strategies, with females showing more pelagic habits and males feeding on carrion to a greater extent than females, at least during the breeding season (Hunter 1983, González-Solís et al. 2000a,b, 2002). The inter-sex differences in mercury concentrations may arise from differential consumption of carrion of penguins as opposed to carrion of Antarctic fur seals Arctocephalus gazella. At Bird Island, northern giant petrel males, which showed the lowest concentration of mercury among giant petrels, are known to feed extensively on carrion of Antarctic fur seal. Although important concentrations of mercury were found in the liver of Antarctic fur seals (215000 $\mathrm{ng} \mathrm{g}^{-1}$ dry weight, Malcolm et al. 1994), concentrations in muscle seem to be very low ( $<50 \mathrm{ng} \mathrm{g}^{-1}$ wet weight; De Moreno et al. 1997), as would be expected from a species that feeds primarily on krill (Croxall \& Pilcher 1984, Reid \& Arnould 1996). However, a comprehensive sampling of potential preys around Bird Island and studies of their mercury levels are needed before reaching clear conclusions on these differences.

\section{Spatial and temporal trends}

Compared with other islands in the South Atlantic and South Indian Ocean, the 2 species of giant petrels are contaminated to a much lesser extent at South Georgia (Table 4). The brown skua mercury levels found at South Georgia were also significantly lower $(3965 \pm 1641 \mathrm{ng}$ $\mathrm{g}^{-1}, \mathrm{n}=10$ ) than those of great skuas from the Shetlands $(6340 \pm 2600, \mathrm{n}=54$, samples from 1994; Stewart et al. 1997; $t=3.781, \mathrm{p}<0.001, \mathrm{df}=18)$. In general, concentrations of mercury in the seabirds analysed are lower than those found in seabirds from other areas where vertically migratory mesopelagic prey seem to have an important role for mercury body burdens of the seabirds (Monteiro et al. 1998). These differences are probably related to the shorter food chain in the Antarctic ecosystem (Honda et al. 1987, Szefer et al. 1993), with krill as an essential prey for many seabird species.

Albatrosses and giant petrels can be considered good species for monitoring long-term changes of mercury in Antarctic and sub-Antarctic waters: firstly, because they are at the top of the food web and can integrate the mercury levels of the food chain, as indicated by their diets and higher values of mercury concentrations compared to other seabird species; secondly, because they cover vast areas while foraging for prey (e.g. Prince et al. 1998, González-Solís et al. 2000a), spatially integrating marine pollution with mercury over large parts of the Southern Ocean; consequently, their mercury burdens reflect background levels at large rather than local scales.

In black-browed and grey-headed albatrosses we found clear signs of an increasing contamination with mercury during the last decade, especially in greyheaded albatrosses whose feather mercury levels had more than doubled over $9 \mathrm{yr}(t=6.218, \mathrm{p}<0.001, \mathrm{df}=$ 31; black-browed albatross: $t=1.213, \mathrm{~ns}, \mathrm{df}=32$ ). In contrast, Thompson et al. (1993) detected no significant change between South Georgia grey-headed albatross mercury contamination before and after 1950. Among 6 species from various sites from the sub-Antarctic only in wandering albatrosses, northern and southern giant petrels from New Zealand have significant increases in mercury levels after 1950 been found. Modelling the at-

Table 4. Spatial and temporal variation in mercury feather levels $\left(\mathrm{ng} \mathrm{g}^{-1}\right)$ in 4 seabird species from the South Atlantic $($ Gough Island, South Georgia) and South Indian Ocean (Marion Island). Data from Thompson et al. (1993b) and this paper

\begin{tabular}{|lcccc|}
\hline Species & Gough Island & Marion Island & \multicolumn{2}{c|}{ South Georgia } \\
& 1985 & 1986 & 1989 & 1998 (this paper) \\
\hline Black-browed albatross & - & - & $4570 \pm 1980$ & $5391 \pm 2049$ \\
Grey-headed albatross & - & - & $4200 \pm 2270$ & $8933 \pm 2851$ \\
Northern giant petrel & - & $19620 \pm 13270$ & - & $4988 \pm 3762$ \\
Southern giant petrel & $11900 \pm 6150$ & $11380 \pm 6400$ & - & $7774 \pm 3571$ \\
\hline
\end{tabular}


mospheric transport of mercury from industrial sources predicted a 4 -fold increase in mercury loads in the northern, but only little increase in the southern hemisphere (Mason et al. 1994, Fitzgerald 1995). This prediction matches closely the temporal trend of mercury contamination of seabirds in the NE Atlantic (Thompson et al. 1992, Monteiro \& Furness 1997). Our results of increasing mercury levels in albatrosses breeding at South Georgia are a first warning that southern oceans may also be affected by the world's ongoing mercury pollution owing to industrial and agriculture emissions which originate mainly from the northern hemisphere.

Acknowledgements. This study was supported by the British Antarctic Survey, Cambridge, and by the research centre TERRAMARE, Wilhelmshaven, Germany. We thank U. Pijanowska for mercury measurements, B. Blöchinger for feather washing and M. Wagener for data handling. Jacob GonzálezSolís held a Marie Curie Fellowship from the European Commission (ERBFMBICT983030) and an incorporation contract from the Departament d'Ensenyament de la Generalitat de Catalunya. We thank José M. Arcos and 3 anonymous referees for helpful comments on the manuscript.

\section{LITERATURE CITED}

Arcos JM, Ruiz X, Bearhop S, Furness RW (2002) Mercury levels in seabirds and their fish prey at the Ebro Delta (NW Mediterranean): the role of trawler discards as a source of contamination. Mar Ecol Prog Ser 232:281-290

Atwell L, Hobson K, Welch HE (1998) Biomagnification and bioaccumulation of mercury in an arctic marine food web: insights from stable nitrogen isotope analysis. Can J Fish Aquat Sci 55:1114-1121

Bargagli R, Monaci F, Sanchez-Hernandez JC, Cateni D (1998) Biomagnification of mercury in an Antarctic coastal food web. Mar Ecol Prog Ser 169:65-76

Becker PH (1992) Egg mercury levels decline with the laying sequence in Charadriiformes. Bull Environ Contam Toxicol 48:162-167

Becker PH, Henning D, Furness RW (1993) The value of chick feathers to assess spatial and interspecific variation in the mercury contamination of seabirds. Environ Monit Assess 28:255-262

Becker PH, Thyen S, Mickstein S, Sommer U, Schmieder KR (1998) Monitoring pollutants in coastal bird eggs in the Wadden Sea: final report of the pilot study 1996-1997. Wadden Sea Ecosystem No. 8. Common Wadden Sea Secretariat, Wilhelmshaven, $\mathrm{p}$ 59-101

Becker PH, Munoz JM, Behrends B, Schmieder KR (2001) Contaminants in bird eggs in the Wadden Sea: temporal and spatial trends 1991-2000. Wadden Sea Ecosystem No. 11. Common Wadden Sea Secretariat, Wilhelmshaven, p 1-68

Bignert A, Litzen K, Odsjö T, Olsson M, Persson W, Reutergardh L (1995) Time-related factors influence the concentrations of SDDT, PCBs and shell parameters in eggs of Baltic Guillemot (Uria aalge), 1961-1989. Environ Pollut 89:27-36

Bowles D (1999) An overview of the concentrations and effects of metal in cetacean species. In: Reijnders PJH, Aguilar A, Donove GP (eds) Chemical pollutants and cetaceans. J Cetacean Res Manage (Spec Issue 1):125-148
Braune BM (1987) Comparison of total mercury levels in relation to diet and molt for nine species of marine birds. Arch Environ Contam Toxicol 16:217-224

Braune BM, Gaskin DE (1987) Mercury levels in Bonaparte's Gull (Larus philadelphia) during autumn moult in the Quoddy region, New Brunswick, Canada. Arch Environ Contam Toxicol 16:539-549

Burger J (1993) Metals in avian feathers: bioindicators of environmental pollution. In: Hodgson E (ed) Review environmental toxicology, Vol 5. Toxicology Communications, Raleigh, NC, p 203-311

Burger J, Gochfeld M (2002) Effects of chemicals and pollution on seabirds. In: Schreiber E, Burger J (eds) Biology of marine birds. CRC Press, Boca Raton, FL, p 485-524

Burger J, Nisbet ICT, Gochfeld M (1994) Heavy metal and selenium levels in feathers of known-aged common terns (Sterna hirundo). Arch Environ Contam Toxicol 26:351-355

Croxall JP, Pilcher MN (1984) Characteristics of krill Euphasia superba eaten by Antarctic fur seals Arctocephalus gazella at South Georgia. Br Antarct Surv Bull 63:117-125

Croxall JP, Prince PA (1987) Seabirds as predators on marine resources, especially Krill, at South Georgia. In: Croxall JP (ed) Seabirds: feeding ecology and role in marine ecosystems. Cambridge University Press, London, p 347-368

Croxall JP, Prince PA, Reid K (1997) Dietary segregation of krilleating South Georgia seabirds. J Zool Lond 242:531-556

De Moreno JEA, Gerpe MS, Moreno VJ, Vodopivez C (1997) Heavy metals in Antarctic organisms. Polar Biol 17:131-140

Elliott JE, Noble DG, Norstrom RJ, Whitehead PE, Simon M, Pearce PA, Peakall DB (1992a) Patterns and trends of organic contaminants in Canadian seabird eggs, 1968-90. In: Walker $\mathrm{CH}$, Livingstone DR (eds) Persistent pollutants in marine ecosystems. Pergamon, Oxford, p 181-194

Elliott JE, Scheuhammer AM, Leighton FA, Pearce PA (1992b) Heavy metal and metallothionein concentrations in Atlantic Canadian seabirds. Arch Environ Contam Toxicol 22:63-73

Fitzgerald WF (1995) Is mercury increasing in the atmosphere? The need for an atmospheric mercury network. Water Air Soil Pollut 80:245-254

Furness RW (1988) Influences of status and recent breeding experience on the moult strategy of the yellow-nosed albatross Diomedea chlororhynchos. J Zool Lond 215:719-727

Furness RW (1993) Birds as monitors of pollutants. In: Furness RW, Greenwood JJD (eds) Birds as monitors of environmental change. Chapman \& Hall, London, p 86-143

Furness RW, Muirhead SJ, Woodburn M (1986) Using bird feathers to measure mercury in the environment: relationships between mercury and moult. Mar Pollut Bull 17:27-30

Furness RW, Lewis SA, Mills JA (1990) Mercury levels in the plumage of red-billed gulls Larus novaehollandiae scopulinius of known sex and age. Environ Pollut 63:33-39

Furness RW, Thompson DR, Becker PH (1995) Spatial and temporal variation in mercury contamination of seabirds in the North Sea. Helgol Meeresunters 49:605-615

González-Solís J, Croxall JP, Wood AG (2000a) Foraging partitioning between giant petrels Macronectes spp. and its relationship with breeding population changes at Bird Island, South Georgia. Mar Ecol Prog Ser 204:279-288

González-Solís J, Croxall JP, Wood AG (2000b) Sexual dimorphism and sexual segregation in foraging strategies of northern giant petrels Macronectes halli during the incubation period. Oikos 90:390-398

González-Solís J, Croxall JP, Briggs DR (2002) Activity patterns of giant petrels Macronectes spp. using different foraging strategies. Mar Biol 140:197-204

Hindell MA, Brothers N, Gales R (1999) Mercury and cad- 
mium concentrations in the tissues of three species of southern albatrosses. Polar Biol 22:102-108

Honda K, Yamamoto Y, Tatsukawa R (1987) Distribution of heavy metals in Antarctic marine ecosystems. Proc NIPR Symp Polar Biol 1:184-197

Hunter S (1983) The food and feeding ecology of giant petrels Macronectes halli and M. giganteus at South Georgia. J Zool Lond 200:521-538

ICES (1999) Seabirds as monitors of marine pollution. ICESCM 1999/C:5:23-47

Kahle S, Becker PH (1999) Bird blood as bioindicator for mercury in the environment. Chemosphere 39:2451-2457

Kruse R (1979) Ein verlustfreier offener Aufschluß mit $\mathrm{HNO}_{3}$ / $\mathrm{HCLO}_{3} / \mathrm{HCLO}_{4}$ für die Bestimmung von Gesamt-Quecksilber in Fischen. Z Lebensm-Unters-Forsch 169:259-262

Lewis SA, Furness RW (1991) Mercury accumulation and excretion in laboratory reared black-headed gull Larus ridibundus chicks. Arch Environ Contam Toxicol 21: $316-320$

Lewis SA, Becker PH, Furness RW (1993) Mercury levels in eggs, internal tissues and feathers of herring gulls Larus argentatus from the German Wadden Sea. Environ Pollut 80:293-299

Lock JW, Thompson DR, Furness RW, Bartle JA (1992) Metal concentrations in seabirds of the New Zealand region. Environ Pollut 75:289-300

Malcolm HM, Boyd IL, Osborn D, French MC, Freestone P (1994) Trace metals in Antarctic fur seal (Arctocephalus gazella) livers from Bird Island, South Georgia. Mar Pollut Bull 28:375-380

Mason RP, Fitzgerald WF, Morel FFW (1994) The biochemical cycling of elemental mercury anthropogenic influences. Geochim Cosmichim Acta 58:3191-3198

Mattig FR, Ballin U, Bietz H, Gießing K, Kruse R, Becker PH (1997) Organochlorines and heavy metals in benthic invertebrates and fish from the back barrier of Spiekeroog. Arch Fish Mar Res 45:113-133

Mattig FR, Rösner HU, Gießing K, Becker PH (2000) Umweltchemikalien in Eiern des Alpenstrandläufers (Calidris alpina) aus Nordnorwegen im Vergleich zu Eiern von Brutvogelarten des Wattenmeeres. J Ornithol 141: 361-369

Monteiro LR (1996) Seabirds as monitors of mercury contamination in the Portuguese Atlantic. PhD thesis, University of Glasgow

Monteiro LR, Furness RW (1995) Seabirds as monitors of mercury in the marine environment. Water Air Soil Pollut 80: 851-870

Monteiro LR, Furness RW (1997) Accelerated increase in mercury contamination in North Atlantic mesopelagic food chains as indicated by time series of seabird feathers. Environ Toxicol Chem 16:2489-2493

Monteiro LR, Furness RW (2001a) Kinetics, dose-response, excretion, and toxicity of methylmercury in free-living Cory's Shearwaters chicks. Environ Toxicol Chem 20: 1816-1823

Monteiro LR, Furness RW (2001b) Kinetics, dose-response, and excretion of methylmercury in free-living adult Cory's Shearwaters. Environ Sci Technol 35:739-746

Monteiro LR, Furness RW, Del Nevo AJ (1995) Mercury levels in seabirds from Azores, mid-north Atlantic Ocean. Arch Environ Contam Toxicol 28:304-309

Monteiro LR, Costa V, Furness RW, Santos RS (1996) Mercury concentrations in prey fish indicate enhanced bioaccumulation in mesopelagic environments. Mar Ecol Prog Ser 141:21-25

Monteiro LR, Granadeiro JP, Furness RW (1998) Relationship between mercury levels and diet in Azores seabirds. Mar Ecol Prog Ser 166:259-265

Monteiro LR, Granadeiro JP, Furness RW, Oliveira P (1999) Contemporary patterns of mercury contamination in the Portuguese Atlantic inferred from mercury concentrations in seabird tissues. Mar Environ Res 47:137-156

Muirhead SJ, Furness RW (1988) Heavy metal concentrations in the tissues of seabirds from Gough Island, South Atlantic Ocean. Mar Pollut Bull 19:278-283

Prince PA, Croxall JP, Trathan PN, Wood AG (1998) The pelagic distribution of South Georgia albatrosses and their relationships with fisheries. In: Robertson G, Gales R (eds) Albatross biology and conservation. Surrey Beatty \& Sons, Chipping Norton, p 137-167

Reid K, Arnould JPY (1996) The diet of Antarctic fur seals Arctocephalus gazella during the breeding season at South Georgia. Polar Biol 16:105-114

Reid K, Trathan PN, Croxall JP, Hill HJ (1996) Krill caught by predators and nets: differences between species and techniques. Mar Ecol Prog Ser 140:13-20

Renner M, Valencia J, Davis LS, Saez D, Cifuentes O (1998) Sexing of adult gentoo penguins in Antarctica using morphometrics. Colon Waterbirds 21:444-449

Stewart FM, Thompson DR, Furness RW, Harrison N (1994) Seasonal variation in heavy metal levels in tissues of common guillemots, Uria aalge, from northwest Scotland. Arch Environ Contam Toxicol 27:168-175

Stewart FM, Phillips RA, Catry P, Furness RW (1997) Influence of species, age and diet on mercury concentrations in Shetland seabirds. Mar Ecol Prog Ser 151:237-244

Stewart FM, Phillips RA, Bartle JA, Craig J, Shooter D (1999) Influence of phylogeny, diet, moult schedule and sex on heavy metal concentrations in New Zealand Procellariiformes. Mar Ecol Prog Ser 178:295-305

Szefer P, Czarnowski W, Pempkowiak J, Holm E (1993) Mercury and major essential elements in seals, penguins, and other representative fauna of the Antarctic. Arch Environ Contam Toxicol 25:422-427

Thompson DR, Furness RW (1989) The chemical form of mercury stored in South Atlantic seabirds. Environ Pollut 60: 305-317

Thompson DR, Hamer HC, Furness RW (1991) Mercury accumulation in Great Skuas Catharacta skua of known age and sex, and its effects upon breeding and survival. J Appl Ecol 28:672-684

Thompson DR, Furness RW, Walsh PM (1992) Historical changes in mercury concentrations in the marine ecosystem of the north and north-east Atlantic Ocean as indicated by seabird feathers. J Appl Ecol 29:79-84

Thompson DR, Becker PH, Furness RW (1993a) Long-term changes in mercury concentrations in herring gulls Larus argentatus and common terns Sterna hirundo from the German North Sea coast. J Appl Ecol 30:316-320

Thompson DR, Furness RW, Lewis SA (1993b) Temporal and spatial variation in mercury concentrations in some albatrosses and petrels from the sub-Antarctic. Polar Biol 13: $239-244$

Thompson DR, Furness RW, Monteiro LR (1998) Seabirds as biomonitors of mercury inputs to epipelagic and mesopelagic marine food chains. Sci Total Environ 213:299-305

Walsh P (1990) The use of seabirds as monitors of heavy metals in the marine environment. In: Furness RW, Rainbow PS (eds) Heavy metals in the marine environment. CRC Press, Boca Raton, FL, p 183-204

Weimerskirch H (1991) Sex-specific differences in moult strategy in relation to breeding in the wandering albatross. Condor 93:731-737 